$\operatorname{Adam} \operatorname{Maj}^{*}$

Warszawa

\title{
Szkoła katolicka w polskim systemie szkolnictwa
}

Dynamika przemian polityczno-społecznych w Polsce - po 1989 roku objęła również system edukacji. Do istotnych przejawów demokratyzacji życia publicznego należy demonopolizacja oświaty, a w sferze organizacyjno-programowej próby reformy szkolnictwa na czele z jej systemową propozycją, wdrażaną od 1999 roku. Jednym z efektów przemian oświatowych tego okresu jest rozwój szkolnictwa katolickiego, wskazujący na jego znaczącą obecność w polskim systemie oświatowym.

Aktualne zagadnienie dla teorii i praktyki pedagogicznej stanowi istota i posłannictwo współczesnej szkoły katolickiej w Polsce oraz jego rozwój i działalność edukacyjna. W literaturze pedagogicznej pojawiły się już analizy różnych aspektów funkcjonowania polskiego szkolnictwa katolickiego. Prezentowane opracowanie stanowi próbę zarysowania syntetycznego obrazu szkoły katolickiej w Polsce w wymiarze teoretycznym (status prawny i koncepcja edukacyjna) oraz empirycznym (stan rozwoju i realizacja programu edukacyjnego).

Na wstępie trzeba stwierdzić, że szkoły katolickie w Polsce stanowią aplikację ich ramowego modelu, określonego w dokumentach Kościoła i nauczaniu Papieża. Najogólniej można stwierdzić, że szkoła katolicka - to instytucja oświatowa, posiadająca wszystkie cechy autentycznej szkoły, o kościelnej specyfice organizacyjnej i programowej. W tym kontekście należy rozpatrywać szkolnictwo katolickie w Polsce.

* Ks. dr Adam Maj - dyrektor szkół katolickich, wykładowca w Szkole Wyższej im. B. Jańskiego w Warszawie, współpracownik Instytutu Pedagogiki Katolickiej. 


\section{Status prawny szkolnictwa katolickiego w Polsce}

Szkoła katolicka jest podmiotem systemu edukacji narodowej i podmiotem kościelnym; jej prawny status reguluje prawo oświatowe oraz prawne ustalenia Kościoła. Dokumenty Kościoła podkreślają, że każda szkoła katolicka powinna być najpierw szkołą. Jan Paweł II wśród istotnych cech szkoły katolickiej wyróżnia jej lojalność wobec prawodawstwa szkolnego danego kraju1. Należy zatem postawić pytanie o status prawny szkoły katolickiej w Polsce oraz o przedmiot jej lojalności w stosunku do systemu edukacji narodowej.

Status prawny szkoły katolickiej określa tzw. prawo oświatowe², na które składa się przede wszystkim ustawa o systemie oświaty ${ }^{3}$ oraz Karta Nauczyciela ${ }^{4}$ i rozporządzenia wykonawcze właściwych resortów rządowych ${ }^{5}$. Zgodnie z ustawą oświatową, szkoła katolicka należy do sektora szkolnictwa niepaństwowego, ponieważ nie jest prowadzona ani przez jednostki samorządu terytorialnego ani resorty rządowe (art. 5). Organem prowadzącym szkolnictwo niepaństwowe może być osoba prawna lub fizyczna, a szkoły publicznymi lub niepublicznymi na prawach publicznych albo bez tych praw (art. 7, 58, 82-88). Tylko szkoły publiczne lub niepubliczne posiadające jej uprawnienia wydają ważne świadectwa, certyfikaty i dyplomy. Do niepaństwowej szkoły publicznej stosuje się zasadniczo wszystkie normy prawa oświatowego, z wyjątkiem rejonizacji. Niepaństwowa szkoła publiczna funkcjonuje bez żadnych opłat uczniowskich. Natomiast niepubliczna szkoła z prawami publicznej zobowiązana jest do realizacji przede wszystkim podstawy programowej kształcenia ogólnego oraz zatrudnienia kwalifikowanych nauczycieli (art. 7.3). Niepaństwowa szkoła publiczna oraz niepubliczna z uprawnieniami publicznej korzysta z subwencji budżetowej państwa (art. 80 i 90), a ich nauczyciele i uczniowie podlegają tym samym obowiązkom i prawom jak nauczyciele i uczniowie szkół państwowych.

Chociaż ustawa oświatowa bezpośrednio nie odnosi się do szkolnictwa katolickiego, bowiem ogólnie traktuje podmioty (organy) szkolnictwa niepaństwowego, to jednak powyższe jej postanowienia mają zastosowanie w procedurze zakładania i sposobie prowadzenia szkoły katolickiej. Kościół katolicki jako instytucja i wspólnota wiernych, honorując prawo oświatowe, organizuje w oparciu o akt założycielski i statut katolicki szkoły publiczne i niepubliczne (art. 58, 84 ustawy oświatowej). Organami prowadzącymi te szkoły są osoby prawne: diecezje (parafie), zakony żeń-

${ }^{1}$ Por. Jan Paweł II, Zaczyn chrześcijański w działalności wychowawczej, Watykan, 29 XII 1978 r., w: Wychowanie w nauczaniu Jana Pawła II (1978-1999), Warszawa 2000, s. 81-82.

${ }^{2}$ Prawo oświatowe trzeba rozpatrywać na szerszym tle polskiego prawodawstwa, w którym pośrednio (np. Konstytucja, art. 30, 48, 53, 70) lub bezpośrednio (np. Konkordat, art. 14; ustawa o gwarancjach wolności sumienia, art. 21-23; ustawa o stosunku Państwa do Kościoła Katolickiego, art. 20-22) gwarantuje się swobodę działalności szkolnictwa katolickiego.

${ }^{3}$ Dz. U. 2004 r. Nr 256, późn. 2572.

${ }^{4}$ Dz. U. 2003 r. Nr 118, późn. 1112, z póz. zm.

${ }^{5}$ Por. Prawo oświatowe na stronach internetowych Ministerstwa Edukacji Narodowej i Sportu. 
skie i męskie, organizacje społeczne (stowarzyszenia, towarzystwa, fundacje) oraz osoby fizyczne. Szkoły katolickie, zgodnie z ich publicznym lub niepublicznym charakterem, podlegają nadzorowi pedagogicznemu w zakresie kształcenia ogólnego.

Powyżej zarysowany status szkoły katolickiej, określony przez polskie prawodawstwo, dopełnia prawodawstwo kościelne. Szkoła katolicka w Polsce jako podmiot kościelny podlega powszechnemu prawu Kościoła i zarazem prawu polskiego Kościoła; jej funkcjonowanie reguluje Kodeks Prawa Kanonicznego oraz postanowienia Konferencji Episkopatu Polski. Ustalenia te mają charakter wewnątrzkościelny, w który nie ingeruje władza państwowa.

Prawo kanoniczne ustala prawa i obowiązki szkoły katolickiej ${ }^{6}$. Najistotniejsze zagadnienie stanowi prawo do korzystania z tytułu szkoła katolicka. Kodeks kanoniczny wskazuje na kompetentną władzę kościelną, za zgodą której szkoła może być uznana za katolicką; taką władzą na terenie diecezji jest biskup diecezjalny (kań. 803, § 1 i 3). Koniecznymi warunkami, jakie w rozumieniu prawa kościelnego powinna spełnić szkoła rzeczywiście katolicka, są: chrześcijański program nauczania i wychowania oraz odpowiednia kadra nauczycieli odznaczających się „zdrową nauką i prawością życia" (kań. 803, § 2). W zakresie kształcenia prawo kanoniczne zobowiązuje szkołę katolicką do zapewnienia uczniom przynajmniej takiego samego poziomu wykształcenia, jaki realizowany jest $\mathrm{w}$ innych szkołach tego samego rodzaju (kań. 806, § 2). Prawo kościelne obliguje biskupa do nadzoru nad każdą szkołą katolicką funkcjonującą na terenie jego diecezji. Nadzór, stanowiący konsekwencję eklezjalnego wymiaru szkoły katolickiej, polega na czuwaniu, wizytowaniu i określaniu ogólnej struktury szkolnictwa katolickiego (kań. 806).

Postanowienia Kodeksu Prawa Kanonicznego bezpośrednio obowiązują polskie szkoły katolickie. Dodatkowymi regulacjami prawnymi, podjętymi w 1994 roku przez Konferencję Episkopatu Polski, są: dokument Wytyczne Episkopatu Polski dotyczqce szkót katolickich ${ }^{7}$ oraz powołanie Rady Szkół Katolickich ${ }^{8}$. Wytyczne uściślają postanowienia prawa kanonicznego i przystosowują je do polskiego prawa oświatowego. Rada Szkół Katolickich, wg statutu nadanego przez Konferencję Episkopatu ${ }^{9}$ jest organizacją kościelną o zasięgu ogólnopolskim, zrzeszającą wszystkie szkoły katolickie. Pierwszorzędnym celem Rady jest koordynacja współpracy między szkołami katolickimi w zakresie prawnym, formacyjnym i programowym. Rada reprezentuje szkolnictwo katolickie wobec polskich władz publicznych i na arenie międzynarodowej. Do najważniejszych przejawów działalności Rady należy wspieranie rozwoju kompetencji prawnej dyrektorów (dwukrotne w ciągu roku zebrania plenarne), prowadzenie doskonalenia zawodowego i formacji nauczycieli (w 2004 roku powołano stosowną placówkę „Pro Formatione”), organizowanie raz w roku ogólnopolskiego forum młodzieży i forum nauczycieli (w 2004 roku odbyło się XV forum).

${ }^{6}$ Por. Kodeks Prawa Kanonicznego, Pallottinum, Poznań 1984, kań. 796-806.

${ }^{7}$ Wytyczne Konferencji Episkopatu Polski dotyczqce szkół katolickich, w: Rada Szkół Katolickich, Informator adresowy o szkołach katolickich, Warszawa 1999, s. 101-106.

${ }^{8}$ Por. strony internatowe Rady Szkół Katolickich: www.rsk.edu.pl i www.szkolykatolickie.pl

${ }^{9}$ Statut Rady Szkół Katolickich, w: Rada Szkół Katolickich, Informator adresowy..., s. 93-99. 
Pokłosiem forum przeznaczonego dla nauczycieli są publikacje, poszerzone o dodatkowe materiały służące rozwojowi pedagogii polskiej szkoły katolickiej ${ }^{10}$. Powyższe inicjatywy stanowią realną troskę Episkopatu Polski o zachowanie i pogłębienie tożsamości szkół katolickich.

Prezentowany stan prawny polskich szkół katolickich ukazuje ich dychotomiczną złożoność. $Z$ jednej strony szkoła katolicka podlega przepisom prawa oświatowego, a z drugiej kieruje się normami prawa kościelnego powszechnego i polskiego. W praktyce te dwa czynniki prawne nie tyle utrudniają działalność szkolnictwa katolickiego, co zwiększają jego odpowiedzialność za jakość edukacji dzieci i młodzieży.

\section{Koncepcja edukacyjna polskiej szkoły katolickiej}

Specyfikę szkoły katolickiej charakteryzuje nie tylko jej złożony status prawny, ale przede wszystkim działalność edukacyjna, która stanowi podstawowe zadanie każdej szkoły. Odpowiedzi na pytanie jakie są najistotniejsze elementy koncepcji edukacyjnej szkoły katolickiej trzeba szukać w jej dwupodmiotowości: kościelnej i w systemie edukacji narodowej. W tym kontekście o edukacji w katolickiej szkole decyduje jej model, określony w dokumentach Kościoła i programie polskiego szkolnictwa, normowany przez prawo oświatowe.

Kształt współczesnej szkoły katolickiej, jej modelową specyfikę edukacyjna, określają dokumenty II Soboru Watykańskiego, zwłaszcza Deklaracja o wychowaniu chrześcijańskim ${ }^{11}$, Stolicy Apostolskiej, szczególnie Kongregacji do Spraw Wychowania Katolickiego ${ }^{12}$, postanowienia Kodeksu Prawa Kanonicznego oraz nauczanie Ojca Świętego Jana Pawła II; w Polsce dodatkowo postanowienia Konferencji Episkopatu i II Synodu Plenarnego ${ }^{13}$.

Analiza dokumentów Kościoła wskazuje, że teoretyczną podstawę szkoły katolickiej stanowi chrześcijańska koncepcja człowieka - jego osobowej istoty ${ }^{14} \mathrm{i}$ integralnej formacji ${ }^{15}$, chrystocentryzm - centralna rola Jezusa Chrystusa ${ }^{16}$, eklezjalny

${ }^{10}$ Por. Rada Szkół Katolickich: Szkoła miejscem kształtowania postawy patriotycznej, Częstochowa 1998 i Wiara fundamentem kultury, Warszawa 2003 r.; a także trzy tomy zeszytów: Szkoła katolicka, red. A. J. Sowiński i A. Dymera, Szczecin 1999 r. (t. 1), 2000 r. (t. 2) i 2001 r. (t. 3).

${ }^{11}$ Deklaracjia o wychowaniu chrześcijański, w: Sobór Watykański II, Konstytucje, dekrety, deklaracje, Pallottinum, Poznań 1967 (skrót: DWCH).

${ }^{12}$ Kongregacja do Spraw Wychowania Katolickiego: Szkoła katolicka, 19 III 1977 r. (skrót: SZK), Świecki katolik świadkiem wiary w szkole, 15 X 1982 r. (skrót: SKW), Religijny wymiar wychowania w szkole katolickiej, 7 IV 1988 r. (skrót: RWW), Szkoła katolicka u progu trzeciego tysiaclecia, 28 XII 1997 r. (skrót: SKT).

${ }^{13}$ Por. Rada Szkół Katolickich w Polsce, Szkoła katolicka w nauczaniu Kościoła. Wybór dokumentów, Szczecin-Warszawa 2002.

${ }^{14}$ Por. SKT 9; SZK 31.

${ }^{15}$ Por. RWW 34.

${ }^{16}$ SZK 34-35, 47, 54-55. 
wymiar jej podmiotowości - zakorzenienie w misji Kościoła ${ }^{17}$ oraz uniwersalizm - otwartość na każdego człowieka ${ }^{18}$. Celem szkoły katolickiej jest integralny rozwój ucznia ku dojrzałości osobowościowej: naturalnej i religijnej oraz przygotowanie go do twórczego uczestnictwa w życiu społecznym i eklezjalnym.

Oryginalny wyróżnik programu pedagogicznego szkoły katolickiej stanowi integracja ewangelizacji i edukacji. Funkcja ewangelizacyjna szkoły przejawia się w koncepcji całości programu edukacyjnego: w wychowaniu i kształceniu ${ }^{19}$. W wychowaniu szkoła realizuje program oparty na Ewangelii Chrystusa, zobowiązujący do syntezy wiary i życia. Chrześcijańskie wychowanie szkolne m.in. przejawia się w formacji religijnej uczniów o różnym doświadczeniu wiary. Zasada wolności i indywidualizacji wyznacza takie formy ewangelizacji, które są właściwe do poziomu religijnego ucznia i jego poszukiwań światopoglądowych. W kształceniu szkoła katolicka przyjmuje zasadę integracji ewangelizacji i kultury przekazywanej w nauczaniu. Jej podstawę stanowi chrześcijańska wizja świata, stworzonego przez Boga i poznawanego $\mathrm{w}$ ramach różnych nauk szczegółowych, zgodnie $\mathrm{z}$ ich autonomiczną metodologią. Proces edukacyjny cechuje harmonia rozumu i wiary, wrażliwość na bogactwo i piękno świata oraz dorobek kulturowy rodziny ludzkiej, a także dialog międzykulturowy. W perspektywie ewangelizacyjnej szkoły katolickiej wiedza „staje się mądrością i koncepcją życia"20.

Ewangelizacja przenikająca dynamicznie edukację, czyli wychowanie i nauczanie, nadaje pedagogii szkoły katolickiej wewnętrzną spójność. O tożsamości szkoły katolickiej decyduje równowaga pomiędzy ewangelizacją i edukacją, umożliwiająca pełną realizację celów humanistycznych i religijnych.

Program edukacji w szkole katolickiej skierowany jest do całego pokolenia młodych, którzy w klimacie wolności i akceptacji pragną w pełni rozwijać swoją osobowość. Nawet wtedy, kiedy motywy wiary nie są przewodnie w wyborze szkoły, młodzi powinni znaleźć we wspólnocie szkoły środowisko przeniknięte wartościami służącymi ich rozwojowi ludzkiemu.

Do etosu szkoły katolickiej należy kształtowanie wspólnoty w środowisku szkolnym, opartej na podmiotowości, współdziałaniu i odpowiedzialności uczniów, nauczycieli i rodziców. Szczególna rola wspólnototwórcza przypada nauczycielom, od których w pierwszym rzędzie zależy jakość kształcenia, wychowania i więzi międzyludzkich w szkole. Od nauczycieli oczekuje się kompetencji dydaktycznych i wychowawczych oraz moralnych - na miarę świadectwa chrześcijańskiego życia.

Nakreślony model szkoły katolickiej, przystosowany do struktury polskiej oświaty, upowszechnia szkolnictwo katolickie. Podmiotowość w systemie edukacji obliguje ka-

${ }^{17}$ Por. DWCH 8; SZK 8-9, 18-20; SKW 3; RWW 33-34; SKT 11-13.

${ }^{18}$ Por. Polski Synod Plenarny (1991-1999), Pallottinum, Poznań 2000, s. 51.

${ }^{19}$ Por. A. Maj, Integracja ewangelizacji i edukacji podstawa tożsamości szkoty katolickiej, w: red. A. Kryński, Ewangelizacja a edukacja w trzecim tysiacleciu, Częstochowa 2002, s. 89-109.

${ }^{20}$ SKT 14. 
tolickie szkoły podstawowe, gimnazjalne i ponadgimnazjalne do realizacji celów, zadań i treści edukacyjnych, określonych przede wszystkim w podstawie programowej ${ }^{21}$.

Dokumenty reformy oraz podstawa programowa wskazują na osobę ucznia jako zasadniczy podmiot szkoły ${ }^{22}$. Personalizacja działalności szkoły określa jej nadrzędny cel, którym jest wszechstronny rozwój ucznia. Zakłada on wielokierunkowe oddziaływania edukacyjne, służące rozwojowi intelektualnemu, fizycznemu, emocjonalnemu, moralnemu, społecznemu i duchowemu. W procesie edukacyjnym wszechstronnemu rozwojowi ucznia ma służyć tzw. triada: nauczanie, kształcenie umiejętności i wychowanie, określona teleologicznie dla każdego typu szkoły. Realizacja triady zmierza do kształtowania ,zintegrowanego systemu wiedzy, umiejętności i postaw" ucznia ${ }^{23}$. Cele edukacji szkolnej zorientowane są aksjologicznie, zwłaszcza w wychowaniu, któremu nadaje się szczególną rolę. Każdą szkołę zobowiązuje się do opracowania spójnych ze sobą programów nauczania, wychowania i profilaktyki, zgodnych z podstawą programowa. Dopełnia je koncepcja opieki, adekwatnej do potrzeb uczniów.

Powyższa ogólna wizja programowa polskiego szkolnictwa stanowi podstawę integracji z ewangelizacyjnym wymiarem katolickiej szkoły. Analiza celów szkolnictwa oraz posłannictwa szkoły katolickiej potwierdza taką możliwość. Wśród zbieżnych elementów obydwu koncepcji należy podkreślić prymat ucznia w działalności edukacyjnej szkoły, jego wszechstronny rozwój jako cel nadrzędny; wyeksponowanie funkcji wychowawczej szkoły, orientację aksjologiczną na wartości uniwersalne, osobowe i moralne; dydaktykę teleologicznie skierowaną na jakość i efektywność; podmiotowy i integrujący wymiar zadań edukacyjnych, realizowanych w nauczaniu, kształceniu umiejętności i wychowaniu ${ }^{24}$.

W tym kontekście, sformułowanie programu katolickiej szkoły każdego typu nie nastręcza ideowych i organizacyjnych trudności. Ustalenie programu nauczania, jako zestawu wszystkich programów kształcenia przedmiotowego i w ramach ścieżek edukacyjnych, polega na odpowiednim ich doborze spośród wielu propozycji i na praktycznie stosowanej zasadzie interpretacji kultury w świetle wiary, ale zawsze z poszanowaniem metodologii nauk. Szkolny program wychowania daje możliwość określenia celów i zadań wychowawczych, zmierzających do wspierania integralnego, pełnego rozwoju ucznia, a więc ujmującego także sferę duchową i religijną. Opracowanie stosownego do diagnozy środowiska szkolnego programu profilaktyki, inspirowanej motywacją chrześcijańską, czyni realnym efektywne kształcenie i wychowanie. Tak ukształtowany, integralny program edukacyjny zawiera w sobie cele

${ }^{21}$ Por. Rozporządzenie MEN w sprawie podstawy programowej wychowania przedszkolnego oraz kształcenia ogólnego w poszczególnych typach szkół, Dz. U. 2002 r. Nr 51, późn. 458.

${ }^{22}$ Por. Ministerstwo Edukacji Narodowej o wychowaniu w szkole, Biblioteczka Reformy nr 13, Warszawa 1999, s. 38-39; Ministerstwo Edukacji Narodowej, Reforma systemu edukacji. Projekt, Warszawa 1999, s. 36-37.

${ }^{23}$ Załącznik nr 2 do rozporządzenia MENiS w sprawie podstawy programowej..., dz. cyt.

${ }^{24}$ Por. Ministerstwo Edukacji Narodowej o wychowaniu, Biblioteczka reformy nr 13, s. 38-39. 
i zadania szkoły katolickiej oraz polskiego szkolnictwa, ustalone w podstawie programowej.

\section{Rozwój szkolnictwa katolickiego w III RP}

Szkoła katolicka, określona organizacyjnie i koncepcyjnie przez prawo oświatowe i nauczanie Kościoła, znalazła sprzyjające warunki rozwojowe w Polsce po 1989 roku. Dynamikę rozwoju szkolnictwa katolickiego w III RP wyznacza wzrost liczby szkół, natomiast charakteryzuje odniesienie do poszczególnych jej typów, do całości polskiego szkolnictwa w stosunku do organów prowadzących.

Obraz rozwoju szkolnictwa katolickiego w III RP, oparty na własnych badaniach autora oraz danych statystycznych Sekretariatu Episkopatu Polski i Rady Szkół Katolickich przedstawia tabela nr 1. Należy zwrócić uwagę, że przy końcu epoki PRL-u i u progu transformacji ustrojowej Polski funkcjonują 24 szkoły katolickie wraz z niższymi seminariami duchownymi (10 seminariów na podbudowie liceum). Trzeba również podkreślić zmianę struktury polskiego szkolnictwa w 1999 roku i wprowadzenie gimnazjum pomiędzy szkołą podstawową i średnią. Szkolnictwo katolickie sprawnie przystosowuje się do zmiany ustroju szkolnictwa, organizując w pierwszym roku wdrażania reformy 63 gimnazja.

Tabela 1. Zbiorcze zestawienie liczby szkół katolickich w latach 1989-2004a

\begin{tabular}{|c|c|c|c|c|c|}
\hline \multirow{2}{*}{ Rok } & \multirow{2}{*}{ Ogółem } & \multicolumn{4}{|c|}{ Liczba szkół według ich typów } \\
\cline { 3 - 6 } & & podstawowa & gimnazjum $^{\mathbf{b}}$ & zawodowa $^{\mathbf{c}}$ & liceum $^{\mathbf{d}}$ \\
\hline 1989 & 24 & - & - & 3 & 21 \\
\hline 1993 & 78 & 18 & - & 6 & 54 \\
\hline 1999 & 276 & 57 & 63 & 37 & 119 \\
\hline 2001 & 350 & 71 & 105 & 33 & 141 \\
\hline 2003 & 405 & 96 & 140 & 25 & 144 \\
\hline 2004 & 413 & 100 & 143 & 27 & 143 \\
\hline
\end{tabular}

a. Dane za: A. Maj, Szkolnictwo katolickie w III RP (1989-2001), Warszawa 2002, s. 172-176 (tab. 1-3); Rada Szkół Katolickich: Informator adresowy szkół katolickich w Polsce, z 2003 i 2004 roku; b. W roku 1989 i 1993 w strukturze szkolnictwa nie funkcjonowało gimnazjum; c. Zawodowa: technikum i zasadnicza; d. Liceum ogólnokształcące (w tym niższe seminarium duchowne) i szkoła policealna.

Analiza danych wskazuje, że w ciągu piętnastu lat nastąpił znaczny wzrost liczby szkół katolickich, ponad 17-krotny w stosunku do stanu z 1989 roku, a bez niższych seminariów duchownych ten wzrost jest 29-krotny. Tendencja rozwojowa utrzymuje 
się również w ostatnich latach, o czym świadczą dane z 2001 i 2004 roku - wzrost liczby szkół o 63 nowe placówki.

W zakresie strukturalnym rozwój szkolnictwa katolickiego nie jest równomierny, chociaż szkoły katolickie funkcjonują we wszystkich typach szkół. Dynamicznie wzrasta liczba gimnazjów - od 63 w 1999 roku do 143 w 2004 roku oraz liceów - od 21 w 1989 roku do 143 w 2004 roku. Trzeba także odnotować rozwój szkół podstawowych, które w 1989 roku w ogóle nie istniały, a w 2004 roku osiągnęły liczbę 100 palcówek. Natomiast nieco zahamowany jest rozwój szkół zawodowych, których liczba w porównaniu ze stanem z 1999 roku (37 szkół zasadniczych i techników) spadła w 2004 roku o 27\% (27 szkół). Wydaje się, że jest to spowodowane aktualną preferencją kształcenia ogólnego w szkolnictwie ponadgimnazjalnym.

Dla obiektywizacji zjawiska rozwoju szkolnictwa katolickiego należy odnieść go do stanu całego szkolnictwa polskiego oraz szkolnictwa niepaństwowego.

Według danych statystycznych GUS ${ }^{25}$ za rok szkolny 2003/2004, w Polsce funkcjonuje 39942 szkół wszystkich typów, w tym dla dorosłych. Szkolnictwo katolickie w 2004 roku w liczbie 413 stanowi niewiele ponad 1\% ogółu liczby szkół w Polsce; bez szkół dla dorosłych (394 szkół katolickich i 36340 wszystkich szkół) - 1,1\% polskiego szkolnictwa.

Nieco inny obraz szkolnictwa katolickiego przedstawia się na tle szkół niepaństwowych. W roku szkolnym 2003/2004 szkoły niepaństwowe w liczbie 5807 wraz ze szkołami dla dorosłych stanowią 14,5\% ogółu szkół w Polsce, a bez szkół dla dorosłych - 4171 szkół niepaństwowych daje 11,5\% udziału w odnośnym szkolnictwie ogólnopolskim. Natomiast szkoły katolickie w ramach szkolnictwa niepaństwowego stanowią 7,1\%, a bez szkół dla dorosłych blisko 9,4\% szkół niepaństwowych.

Rozwój szkolnictwa katolickiego nie jest równomierny we wszystkich częściach kraju, chociaż szkoły katolickie - wg danych z 2004 roku - funkcjonują we wszystkich województwach i diecezjach ${ }^{26}$. Analiza sieci szkół katolickich w układzie administracji państwowej i kościelnej nasuwa zasadniczy wniosek: szkoły katolickie rozwijają się w środowiskach o największej liczbie mieszkańców, np. w województwie mazowieckim - 73 szkoły, w diecezji krakowskiej - 42 szkoły albo największej gęstości zaludnienia, np. w województwie śląskim - 52 szkoły i przede wszystkim w dużych miastach. Wydaje się, że lokalizację szkoły katolickiej warunkuje odpowiednia populacja mieszkańców i potencjalnych uczniów oraz ich status finansowy. Ważny czynnik lokalizacji stanowi również możliwość skompletowania odpowiedniej kadry nauczycieli oraz zorganizowania stosownej bazy lokalowej, a taka szansa pojawia się zazwyczaj w większych miejscowościach, między innymi w infrastrukturze wielkomiejskich parafii, klasztorów lub instytucji państwowych czy samorządowych.

${ }^{25}$ Por. Główny Urząd Statystyczny, Mały rocznik statystyczny Polski 2004, Warszawa 2004, s. $218,221-222$.

${ }^{26}$ Por. Rada Szkół Katolickich, Informator adresowy szkót katolickich w Polsce, Warszawa 2004. 
Charakterystyczny aspekt szkolnictwa katolickiego w III RP stanowi analiza jego rozwoju w odniesieniu do organów prowadzących szkoły. Dane statystyczne w tym zakresie prezentuje tabela $\mathrm{nr} 2$.

Tabela 2. Szkoły katolickie według organów prowadzących w latach 1989-2004a

\begin{tabular}{|l|c|c|c|c|c|c|}
\hline \multirow{2}{*}{ Organ prowadzący } & \multicolumn{7}{|c|}{ Dane statystyczne z roku } \\
\cline { 2 - 7 } & $\mathbf{1 9 8 9}$ & $\mathbf{1 9 9 3}$ & $\mathbf{1 9 9 9}$ & $\mathbf{2 0 0 1}$ & $\mathbf{2 0 0 3}$ & $\mathbf{2 0 0 4}$ \\
\hline Instytucje diecezjalne $^{\mathrm{b}}$ & 2 & 15 & 54 & 80 & 93 & 94 \\
\hline Zakony męskie $^{\mathrm{c}}$ & 10 & 22 & 77 & 94 & 98 & 100 \\
\hline Zakony żeńskie $^{\mathrm{d}}$ & 12 & 19 & 51 & 62 & 71 & 74 \\
\hline Organizacje społeczne $^{\mathrm{e}}$ & - & 22 & 86 & 104 & 131 & 133 \\
\hline Osoby fizyczne & - & - & 8 & 10 & 12 & 12 \\
\hline Ogółem & 24 & 78 & 276 & 350 & 405 & 413 \\
\hline
\end{tabular}

a. Źródło danych: patrz legenda tabeli nr 1, punkt a.; b. Diecezja i parafia; c. Męskie instytuty życia konsekrowanego i stowarzyszenia życia apostolskiego; d. Żeńskie instytuty życia konsekrowanego i stowarzyszenia życia apostolskiego; e. Stowarzyszenia i fundacje.

Wyniki badań wskazują, że wszystkie uprawnione przez polskie prawo oświatowe podmioty prowadzą szkoły katolickie. Organem prowadzącym największą liczbę szkół w 2004 roku są organizacje społeczne - ponad 32\% wszystkich szkół katolickich, męskie zakony - ok. 24\%, następnie diecezje i parafie - ok. 23\%, żeńskie zakony - ponad 17\%, a najmniejszą liczbę szkół - ok. 3\% - osoby fizyczne. Zaangażowanie różnych podmiotów w działalność szkolnictwa katolickiego wpisuje się w zmiany ustrojowo-społeczne zachodzące w Polsce i w Kościele oraz w zwiększającą się rolą świeckich katolików.

\section{Edukacyjna działalność w polskich szkołach katolickich w badaniach}

Istotne zagadnienie teoretyczne i praktyczne stanowi działalność pedagogiczna szkół katolickich w Polsce. Należy postawić pytanie o podstawy ich programu edukacyjnego oraz realizację wyznaczonych celów i zadań. Wstępną odpowiedź na powyższe pytanie zawierają wyniki badań nad szkolnictwem katolickim w III RP przeprowadzonych przeze mnie w 2001 roku. Badaniami, polegającymi na analizie statutów i programów edukacyjnych oraz odpowiedzi dyrektorów na pytania kwestionariusza ankiety, objęto 202 szkoły. W oparciu o wyniki badań można zarysować syntetyczny obraz działalności edukacyjnej katolickich szkół w wychowaniu, dydaktyce i opiece ${ }^{27}$.

${ }^{27}$ Szczegółowe wyniki badań i ich analizę zawiera publikacja A. Maja: Szkolnictwo katolickie w III RP (1989-2001), s. 213-273. 
Zgodnie z założeniami reformy i normami prawa oświatowego, działalność wychowawczą szkoły określają ustalenia statutu oraz program wychowawczy. Biorąc pod uwagę koncepcję edukacyjną szkoły katolickiej, zasadne jest pytanie o podstawę aksjologiczną jej sfery wychowawczej. Przyjmując interpretację celów wychowania jako wartości i norm społecznych świadomie określonych i wdrażanych w wychowaniu, stawiamy pytanie, jakie cele i zadania wychowawcze wyznaczają szkoły katolickie w swoich statutach? Badania wskazują, że statuty szkół katolickich zawierają cele i zadania ukierunkowane na wartości osobowe i moralne. Wartości osobowe skupione są wokół promujących rozwój duchowy i religijny ucznia. Spośród wartości moralnych na uwagę zasługują wartości zgrupowane wokół Dekalogu i miłości oraz patriotyzmu i poszanowania dla innych kultur. Wskazane w statutach wartości ukierunkowane są na integralny rozwój ucznia na fundamencie wiary, zmierzający do jego chrześcijańskiej dojrzałości osobowościowej. Analiza programów wychowawczych wskazuje, że ich podstawę aksjologiczną stanowią przede wszystkim wartości zawarte w Dekalogu i Ewangelii. Eksponowane są takie wartości, jak: Bóg, wiara, miłość, piękno, przebaczenie, wierność, dobroć, wrażliwość, wspólnota, godność, szacunek, odpowiedzialność, pobożność. Drugą grupę stanowią wartości patriotyczne, podkreślające chrześcijańskie tradycje narodu polskiego. Trzecią grupę tworzą wartości skupione wokół charyzmatu patrona szkoły lub preferowane przez znane autorytety kościelne, np. św. Jana Bosko, św. Franciszka, Jana Pawła II. Analiza badań wskazuje na spójność systemu aksjologicznego wychowania zawartego programach wychowawczych i w statutach szkół.

W zakresie dydaktycznym jednym z głównych zadań reformowanej szkoły stanowi budowanie nowej pedagogii, opartej na podstawie programowej i aktywnych metodach nauczania. Tę szansę w znacznym stopniu wykorzystują nauczyciele katolickich szkół, którzy w blisko 42\% szkół wdrażają autorskie programy. W badanych szkołach wprowadzono także dodatkowe przedmioty, które stanowią element tożsamości szkoły i wychodzą naprzeciw potrzebom uczniów, np. filozofię, łacinę, ekologię, taniec towarzyski, zajęcia medialne i dziennikarskie. Do preferowanych zagadnień dydaktycznych w statutach szkół podstawowych należą: poszukiwanie sposobów wszechstronnego rozwoju osobowości uczniów, ich zainteresowań poznawczych, talentów i potrzeby twórczości (37\% ankietowanych szkół) oraz nauczanie zgodne z zasadami Ewangelii (27,5\%). W gimnazjach w centrum uwagi znajduje się wysoki poziom wiedzy i umiejętności oraz wyboru kierunku dalszego kształcenia (49,2\% badanych szkół), kształcenie młodzieży w oparciu o doktrynę chrześcijańską (39,3\%), rozwijanie zainteresowań uczniów $(34,4 \%)$. W szkołach zawodowych na pierwszym miejscu podkreślone jest zdobycie szerokiej wiedzy i umiejętności na określonym poziomie kształcenia (36,3\% badanych szkół), a także przygotowanie do odpowiedzialności za podejmowane zadania $(27,3 \%)$, wspomaganie w dokonaniu wyboru dalszego kształcenia $(18,2 \%)$. W liceach w centrum uwagi znajduje się przygotowanie do matury i studiów wyższych (83,3\% ankietowanych szkół), następnie nauczanie na zasadach doktryny chrześcijańskiej, w tym społecznej nauki Kościoła 
$(57,7 \%)$, wszechstronny rozwój intelektualny ucznia $(35,6 \%)$, stosowanie indywidualnych programów nauczania $(20,0 \%)$.

Adekwatna i skuteczna opieka nad uczniami jest istotnym przejawem personalizacji działalności szkoły. Podstawowe wyzwanie, stojące przed szkołą katolicką w sferze opieki, stanowi zapewnienie dostępności do niej uczniom pochodzącym z niezamożnych rodzin. W tym zakresie podejmowanych jest wiele form opieki, jak pełne zwolnienie z opłat $(39,6 \%$ badanych szkół), częściowe $(56,4 \%)$ oraz opieka stypendialna (17,8\%). W trosce o zapewnienie posiłków dla dzieci i młodzieży stosuje się różne formy dożywiania, najczęściej poprzez sklepiki szkolne $(46,5 \%$ ankietowanych szkół) i stołówkę (37,1\%). Opieka nad uczniami znalazła swój wyraz w zapisach statutowych. W szkołach podstawowych preferuje się stałą opiekę nad uczniami przebywającymi w szkole w ramach zajęć świetlicowych i pozalekcyjnych (60\% badanych szkół podstawowych), pomoc pedagogiczna, medyczna, psychologiczną, logopedyczną, opiekę nad dziećmi z mikrodefektami (55\%). W gimnazjach szczególną uwagę przywiązuje się do stworzenia optymalnych warunków psychofizycznego rozwoju uczniów; w tym celu podkreśla się dożywianie, zapobieganie uzależnieniom, dowożenie i odwożenie uczniów (78,6\% ankietowanych gimnazjów). W szkołach zawodowych eksponuje się indywidualną troskę o ucznia, której wyrazem są zajęcia uzupełniające lub pogłębiające wiedzę ( $36,4 \%$ badanych szkół zawodowych) oraz opiekę zdrowotną i psychologiczno-pedagogiczną (27,3\%). W liceach dominuje troska o rozwój psychiczny i zdrowotny wychowanków; w tym celu tworzy się gabinety lekarskie, realizuje programy prozdrowotne i profilaktyczne $(66,7 \%$ ankietowanych liceów). Podkreśla się także troskę o indywidualny rozwój poznawczy wychowanków, organizując różne formy pomocy uczniom uzdolnionym i mającym trudności w nauce $(60 \%)$.

Wyniki badań i ich analiza wskazuje, że w wypełnianiu funkcji wychowawczej, dydaktycznej i opiekuńczej szkoły katolickie podejmują różnorodne działania wynikające z teoretycznych założeń szkoły katolickiej, realizując jednocześnie podstawowe cele szkoły, określone w prawie oświatowym.

Zarysowany obraz współczesnego szkolnictwa katolickiego w Polsce przedstawia jego złożoność prawną, organizacyjną i edukacyjną, wynikającą z podmiotowości kościelnej w systemie oświaty. W organizacji szkoły katolickiej tożsamościowy wyróżnik stanowi integracja koncepcji szkoły, określonej przez Kościół i prawo oświatowe, natomiast w działalności pedagogicznej integracja ewangelizacji i edukacji. Analiza wyników badań empirycznych potwierdza możliwość konstrukcji integralnego programu edukacyjnego, jednoczącego posłannictwo szkoły katolickiej z celami programowymi polskiej szkoły.

W wyniku przemian ustrojowych po 1989 roku i aktywności różnych podmiotów Kościoła, dokonuje się znaczący rozwój ilościowy szkolnictwa katolickiego - od 24 szkół w 1989 roku do 413 w 2004 roku, ale w stosunku do ogółu szkolnictwa polskiego pozostaje marginesowy - ok. 1\% jego stanu. Ważnym zadaniem szkolnictwa katolickiego jest jego rozwój jakościowy, który implikuje aktywność innowacyjną. Badania wskazuja, że w szkołach katolickich wprowadza się innowacje wychowaw- 
cze i dydaktyczne, a w mniejszej liczbie szkół opiekuńcze ${ }^{28}$. Intensyfikacja działalności innowacyjnej, orientującej ku szkole twórczej oraz dynamiczna wierność chrześcijańskiej misji zdecyduje nie tylko o rozwoju jakościowym szkolnictwa katolickiego, lecz także ilościowym. Dla jakości polskiej oświaty korzystny jest rozwój autentycznych szkół katolickich.

\section{Catholic schools in Polish educational system (Summary)}

The changes in political and educational systems in Poland after 1989 gave way to the development of catholic schools which have become a rightful element of the system of education. Catholic school is a complex phenomenon; it is both an educational institution of the Church and the Polish system of education. The organizational specificity of a catholic school is based on the concept of school specified by the Church and educational law. The pedagogical specificity consists of the integration of both religious and general education. The analysis of the documents of the Church and the system of education, which is being reformed, confirms the possibility of creating an integral educational programme uniting the mission of the catholic school with the programme targets of Polish school. This programme is executed by various types of catholic schools, the number of which has grown rapidly from 24 in 1989 to 413 in 2004 (approximately 1\% of all schools in Poland). One of the important tasks of catholic education is the development of its quality which implies innovative activity. The research shows that educational and didactic innovations are introduced in catholic schools, but not all of them introduce protective innovations. The intensification of innovative activity aiming at creative school and dynamie faithfulness of Christian mission will decide on the quality and quantity development of catholic education. The development of authentic catholic schools is advantageous for the quality of the whole educational system in Poland.

${ }^{28}$ Tamże, s. 266-273. 